\title{
The bumpy road of biomass gasification in the Netherlands: Explaining the rise and fall of an emerging innovation system
}

\author{
Simona O. Negro*, Roald A.A. Suurs, Marko P. Hekkert \\ Utrecht University, Copernicus Institute for Sustainable Development and Innovation, Department of Innovation Studies, \\ Heidelberglaan 2, 3584 CS Utrecht, The Netherlands
}

Received 8 May 2006; received in revised form 15 August 2006; accepted 16 August 2006

\begin{abstract}
In this paper, the concept of System Functions of Innovation Systems is applied to provide an explanation of the success or failure of an emerging technology, i.e. biomass gasification, with empirical data on the evolution of this technology in the Netherlands during 1980-2004. A new list of System Functions has been developed lately and is used to identify the most relevant events in the evolution of the Biomass Gasification Innovation System. We show that a structural misalignment occurred between the institutional framework within which the technology could have been developed and the technical requirements of the technology. Finally, the absence of System Functions such as the guidance of the search, resource allocation and advocacy coalition explains the failure of this technology over time.
\end{abstract}

(C) 2006 Elsevier Inc. All rights reserved.

Keywords: System Functions; Dynamics; Transition

Abbreviations: BSE, Resolution Subsidy Energy Program; CHP, Combined Heat and Power; ECN, Energy Research Centre of the Netherlands; EWAB, Energy production from Waste and Biomass; MEP, Environmental Quality Electricity Production; Ministry of EZ, Dutch Ministry of Economic Affairs; NMP, National Environmental Policy Plan; NOB, National Research Program on Biomass Gasification; NOH, National Research Program for Recycling of Waste; NOVEM, Netherlands Agency for Energy and Environment; PDE, Dutch Office for Renewable Energies; REB, Regulating Energy Tax; RIVM, National Institute for Public Health and the Environment; SI, Systems of Innovation; SMB, Cooperation of Middle-Brabant County; STEG, Steam and Gas Turbine; STIG, Steam-injected Gas Turbine; TNO, Netherlands Organisation for Applied Scientific Research; TNOMEP, TNO Environment, Energy and Process Innovation; TSIS, Technology Specific Innovation System; VROM, Netherlands Ministry of Housing, Spatial Planning and the Environment.

* Corresponding author. Tel.: +3130 253 7166; fax: + 31302532746.

E-mail address: s.negro@geo.uu.nl (S.O. Negro). 


\section{Introduction}

The issue of stimulating the development, diffusion, and application of renewable energy (renewables) remains high on the political agenda of many countries. Despite numerous attempts in this direction, such as the set up of European research programs for the demonstration and promotion of renewable energies, ${ }^{1}$ it has proven to be difficult to replace large quantities of fossil fuels with renewable alternatives. Actually, the renewable energy supply for IEA $^{2}$ countries has increased from $4.6 \%$ of the total primary energy supply in 1970 to $5.5 \%$ of the same in 2001 [1]. However, Jacobsson and Johnson [2] counter these disappointing figures by noting that a process of diffusion of renewables is now starting to take place. They base this more optimistic message on the high annual growth rates of different renewable energy sources. The annual growth of total renewables supply has been $2.3 \%$ over the last 33 years. Notably, the same for new renewables (including geothermal, solar, and wind) has been $8 \%$ during the same period. Despite such high growth rates, the share of renewable energy sources in global Total Primary Energy Supply (TPES) remains low due to the vast size of the global energy market.

The current situation of heavy dependency on fossil fuels ${ }^{3}$ and the difficulty for renewables to have a major breakthrough is captured well by the term: 'carbon lock-in' [3]. Under this condition, fossil fuel technology benefits from long periods of experience, leading to high efficiency, low costs, optimal institutional arrangements, and many vested interests [3]. As a result, the emerging market for renewables has to depend very much on government support to expand. Many obstacles are also to be overcome in order to realize their smooth diffusion. Since these obstacles differ for each country and for each technology, our knowledge on the diffusion process of renewable technologies is limited. More insight is, therefore, needed on the process through which renewable technologies emerge and how they are able to achieve successful diffusion in society.

From the earlier studies on the transformation of energy system [4,5], we have learned that the success of a new technology is not only determined by its technical characteristics but also by the ability of the Innovation System (IS) that develops, diffuses, implements, or rejects new biomass technologies. A well functioning IS vastly improves the chances for the success of the technology in question to be developed and diffused.

In this paper, we analyze the development and diffusion of biomass gasification technology in the particular context of the Netherlands. The choice of this technology is justified by the fact that biomass is considered to be one of the most promising alternatives to replace fossil fuels since it is a diverse energy carrier with a multitude of potential sources and applications. The gasification technology, in turn, is generally considered to be a very promising technology to convert biomass into useful products. First, the conversion efficiency of biomass into electricity is much higher than that for biomass combustion and digestion. Second, by means of gasification, besides the production of electricity, biomass can also be converted into feedstock for the chemical industry and for the production of liquid biofuels. The expectations around this technology are, therefore, quite high and many actors see it as the technology to achieve a breakthrough for biomass as modern energy source [6-9]. However, despite its high efficiency, wide range of applications, and high expectations, biomass gasification has not been successfully developed, diffused, and implemented in the Netherlands so far.

\footnotetext{
${ }^{1}$ Thermie - (1990-1994) 'Non-nuclear energy RTD Programme', 700 million Euros, and Joule — 'Non-Nuclear Energy research programme' (1991-1994).

2 International Energy Agency.

${ }^{3}$ Fossil fuels make up a percentage of $86.7 \%$ of the world TPES: $34.4 \%$ Oil, $21.2 \%$ Gas, $24.4 \%$ Coal, $6.5 \%$ Nuclear and $13.3 \%$ Renewables [1].
} 
Our main research question, therefore, is: What are the inducement and blocking mechanisms that have determined the evolution of biomass gasification in the Netherlands?

This question is addressed by utilizing the Innovation System concept as a framework and the empirical data on the evolution of this technology in the Netherlands during 1980-2004.

\section{Technological change and Innovation Systems}

The underlying theory of this paper focuses on how to break out of the 'lock-in' of established systems and how to resolve the difficulty that firms encounter when developing new technologies and bringing them to the market. Unruh [3] argues that "industrial economies have been locked into fossil fuel-based energy systems through a process of technological and institutional co-evolution driven by pathdependant increasing returns to scale." He calls this situation 'carbon lock-in', since it creates persistent market and policy failures, which inhibit the diffusion of carbon-saving technologies despite their apparent environmental and economic advantages. Unruh [3] argues further that the "lock-in occurs through combined interactions among technological systems and governing institutions, which perpetuate fossil fuel-based infrastructure in spite of their known environmental externalities and the apparent existence of cost-neutral, or even cost-efficient, remedies". These technological systems can be regarded as large complex systems of technologies embedded in a powerful conditioning social context of public and private institutions. It is this context that determines how technological systems evolve.

We focus on a specific part of this social context that we label as the IS. This is the set of actors and institutions that determine the generation, diffusion, and utilization of a new technology. The Energy Innovation System is part of the overall Innovation System and leads to the generation and diffusion of innovations that are used in the energy system. Once an Energy Innovation System is focused on specific technological trajectories such as the more efficient fossil fuel conversion technologies, alternative technologies can be locked-out for a long time even if they demonstrate improvements upon the established systems [3]. It is impossible to isolate a single factor that could unlock the system. However, the existing Innovation System could lose viability when the selection environment changes and starts providing new challenges that cannot be met by the dominant technological trajectories or that require advances, which are possible only at very high marginal cost [10]. This opens the windows of opportunities for the new technologies. But, such opportunities in and of themselves are not sufficient to unlock the system. Many opposing forces are likely to slow down or even stop the successful development and diffusion of emerging technologies. So, what is needed to increase the chance of new technology development to become successful?

The theoretical model we use in this paper is based on the notion that when a new technology, in our case biomass gasification, is invented, an emerging Technology Specific Innovation System (TSIS) surrounds it. For this technology to become successful, several activities need to occur within the emerging TSIS, especially those needed to develop, support and implement the technology. As an illustration, a possible course of activities is described subsequently. In the initial phase, the TSIS is bound to consist of merely scientists and engineers, who invent and further develop the technology due to specific policy goals. Then, they would persuade financers to invest in R\&D by presenting high economic returns for the technology. As technological success augments, so do the expectations. This, in turn, leads to further growth of the TSIS as more actors are likely to enter and specific institutions are set in place to support the technology. With the flow of financial resources, more technology developers pick up the new line of research. At a certain point, policy makers also enter into the system as subsidies, development programs, or niche markets are developed for the new technology. Thus, the TSIS grows both in size and 
Table 1

Set of Function of Innovations Systems

Functions of Innovation Systems

F1: Entrepreneurial Activities

F2: Knowledge Development (learning)

F3: Knowledge Diffusion through Networks

F4: Guidance of the Search

F5: Market Formation

F6: Resource Mobilization

F7: Counteracting Resistance to Change (also Support from Advocacy Coalitions)

influence and it co-evolves with technological development. At a certain point, the sheer size of the TSIS is so large that it is able to take over large parts of the incumbent Energy Innovation System (creative destruction).

Our main point of interest here, therefore, is: what are the determining factors that foster the growth of an emerging TSIS, entrenching it in society and allowing it to gain ground in the existing Energy Innovation System?

Edquist [11] states that these determining factors can be traced by identifying all processes that take place in the IS, influencing the development, diffusion, and application of an innovation. These processes are also called 'Functions of Innovation Systems', which are referred from here on as System Functions. Jacobsson and Johnson, who developed the concept of a System Function, define it as "a contribution of a component or a set of components to a system's performance", where the components are actors, relations between actors, and institutions and the performance is considered in terms of the rate of development, diffusion, and implementation of a new technology [2]. They argue that an Innovation System "may be described and analyzed in terms of its 'functional pattern', i.e., in how these functions have been served" [2]. The functional pattern can be mapped by studying the dynamics of each System Function separately plus the interdependencies among the System Functions. By assessing the functional pattern, insight is created into the performance of an IS. Thus, to understand the inducement and blocking mechanisms of technology development, diffusion, and implementation, the functional pattern of the related TSIS needs to be described and analyzed, particularly through time. Depending on the phase of development of the innovation system, we can expect differences in the functional patterns.

In earlier works within the literature [2,11-14], different sets of System Functions are proposed. In this article we build on the work of Hekkert et al. [5], who propose the set of System Functions, ${ }^{4}$ as shown in Table 1.

We expect that the more System Functions are fulfilled, the better the performance of the IS will be, resulting in, thereby, higher chances for a successful development, diffusion, and implementation of new technologies.

Both the individual fulfillment of each System Function and the interaction dynamics among the functions are of importance. Virtuous interaction patterns between System Functions could lead to a reinforcing dynamic within the IS, whereas vicious interactions could cause the IS to collapse eventually. For example, an increase in knowledge and positive research results can lead to high expectations of the emergent technology, attracting new actors and additional resources for the development of the emergent technology. Obviously, this leads to more research activities being initiated (see Fig. 1).

\footnotetext{
${ }^{4}$ For a full description of these functions, see [5].
} 


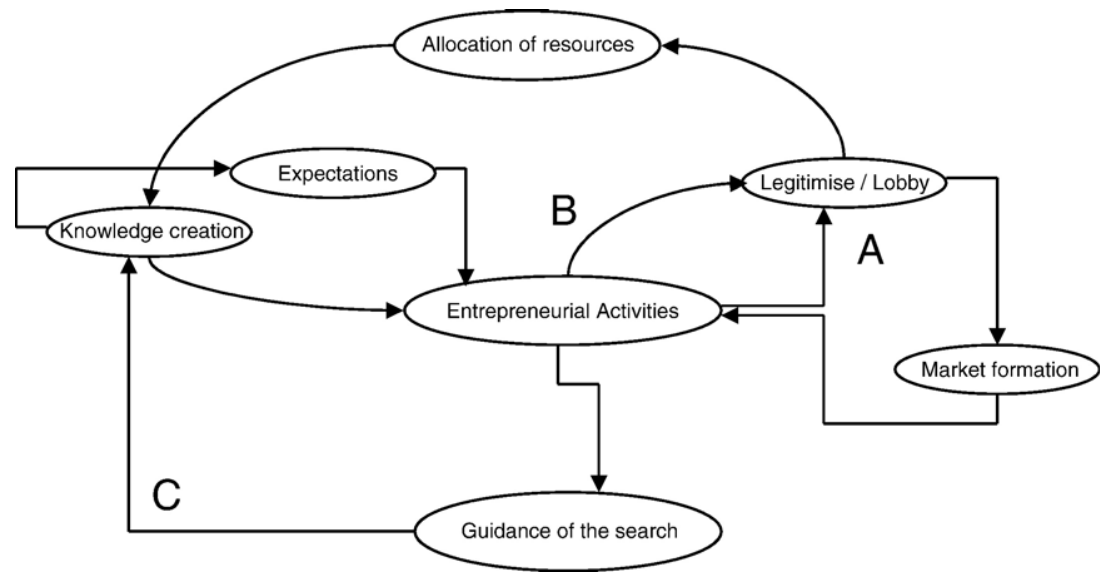

Fig. 1. Overview of possible reinforcing cycles within an IS.

Apart from the reinforcing cycles, vicious cycles can also be active within the system. For instance, a negative fulfillment of a function might lead to negative outcomes with respect to the fulfillment of other functions, resulting in a declining functional pattern. In this case, the cycle might bring down the whole system before it eventually collapses. An example in this respect could be the cutback of a national subsidy program and its negative impacts on the expectations over the possible success of the technology. This would cause entrepreneurs to stop their activities, thus further decreasing the expectations, which eventually would lead to the abolishment of the remaining subsidies.

The practical relevance of this framework is that policy initiatives directed at stimulating sustainable change of the energy system, should focus on stimulating weak System Functions to increase the chances of virtuous feedback taking place. Additionally, by identifying the underlying tendencies of the occurrence of vicious cycles, appropriate policy recommendations can be developed to prevent or resolve the occurrence of those cycles in the future. For a thorough understanding of these processes, historical empirical analyses are necessary. Moreover, since the dynamics are often specific to both technology and nation, a focus on a particular technology within the institutional context of one country is justified ${ }^{5}[15]$. Below we describe how we analyzed the dynamics of the Biomass Gasification Innovation System in the Netherlands.

\section{Methodology}

\subsection{Historical Event Analysis}

We propose to use as much quantitative indicators as possible in order to be able to map functional patterns over time. For this purpose, we developed a method inspired by 'Historical Event Analysis' as used by Van de Ven et al. [16] and Poole et al. [17]. Stemming from organizational theory, their focus is mainly on the company and company networks. But, in our case, the analysis is applied to a technological

\footnotetext{
${ }^{5}$ We are aware that technology developments in foreign countries influence developments in the Netherlands. For example in Lahti, Finland and Ruien, Belgium successful gasification projects took place. However, to understand the inducement or blocking mechanisms that determine the evolution of biomass gasification in the Netherlands, the analysis will be restricted to the actors, institutions, organizations and their mutual interactions within the Netherlands [15].
} 
system level. Basically, our approach consists of retrieving as many historical events related to a technological development as possible. Such information is gathered essentially from professional journals, newspapers, and websites. The events are stored in a database with a systematic classification and allocation to the System Functions. The methodology results in a coherent sequence of events related to the development, diffusion, and implementation of biomass gasification in the Netherlands during 1980-2004. This sequence is, then, the basis for the storyline that empirically describes the evolution of biomass gasification. The events are also plotted for a graphic description of the functional patterns.

To construct the functional patterns, all events are weighed the same. However, in the storyline some relevant events are highlighted by naming them explicitly. A distinction should be made regarding the nature of the contribution of an event to the fulfillment of a system function. Some events have a positive contribution to the development of the technology, while others contribute negatively as, for instance, an expression of disappointment or the opposition of an important political group. The positive and negative events are counted and represented separately. This way the functional pattern might yield specific insight into the controversies that emerge around the analyzed technology.

Table 2

Overview of the operationalisation of the System Functions

\begin{tabular}{|c|c|c|c|}
\hline Function & Activity & Sign/value & $\begin{array}{l}\text { Number of events } \\
\text { per function }\end{array}$ \\
\hline \multirow{2}{*}{$\begin{array}{l}\text { Function 1: } \\
\text { Entrepreneurial } \\
\text { Activities }\end{array}$} & Project started & +1 & 30 \\
\hline & Project stopped, not completed & -1 & 23 \\
\hline \multirow{2}{*}{$\begin{array}{l}\text { Function 2: Knowledge } \\
\text { Development }\end{array}$} & $\mathrm{R} \& \mathrm{D}$ projects, Investment in $\mathrm{R} \& \mathrm{D}$ & +1 & 64 \\
\hline & Desktop/Assessment/Feasibility studies on gasification & & \\
\hline $\begin{array}{l}\text { Function 3: Knowledge } \\
\text { Diffusion }\end{array}$ & Workshops, conferences & +1 & 32 \\
\hline \multirow{2}{*}{$\begin{array}{l}\text { Function 4: Guidance of } \\
\text { the Search }\end{array}$} & Positive expectations on gasification, regulations by government & +1 & 84 \\
\hline & $\begin{array}{l}\text { Negative expectations on gasification, lack of } \\
\text { regulations by government }\end{array}$ & -1 & -15 \\
\hline \multirow{2}{*}{$\begin{array}{l}\text { Function 5: Market } \\
\text { Formation }\end{array}$} & Specific tax regimes, feed-in rates, environmental standards & +1 & 3 \\
\hline & Lack of tax regimes, lack of environmental standards & -1 & 0 \\
\hline \multirow[t]{2}{*}{$\begin{array}{l}\text { Function 6: Resource } \\
\text { Mobilization }\end{array}$} & $\begin{array}{l}\text { Subsidies, investments for gasification, biomass streams } \\
\text { allocated to project }\end{array}$ & +1 & 21 \\
\hline & $\begin{array}{l}\text { Expressed lack of subsidies, investments, expressed } \\
\text { lack of biomass streams allocated to project }\end{array}$ & -1 & -4 \\
\hline \multirow[t]{2}{*}{$\begin{array}{l}\text { Function 7: Advocacy } \\
\text { Coalition }\end{array}$} & $\begin{array}{l}\text { Support by government/industry that legitimizes } \\
\text { the use of the technology }\end{array}$ & +1 & 7 \\
\hline & Expressed lack of support by government, industry & -1 & 0 \\
\hline
\end{tabular}

For the functions 'Market Formation' and 'Advocacy Coalition', too little data are obtained (a total of 3 and 7 events respectively), thus they are not represented graphically. For the function 'Knowledge Development', the event category 'Evaluative Content' represents reflections by actors on either the development of the IS in general, or on biomass gasification technology in particular; both are represented in a separate figure. For the function 'Resources Mobilization', the availability of biomass streams and project investments are represented in the positive line, whereas the expressed lack of physical and financial resources is represented in the negative line. 
The fulfillment of the System Functions is represented by graphical activity patterns, where per function, events are aggregated per year. A positive line represents the total amount of activities per year that contribute positively, whereas a negative line represents activities that contribute negatively to that particular function. The graphs are used to illustrate the qualitative storyline about the dynamics of the biomass gasification IS that is extracted from the sequence of events.

Table 2 shows the scheme of how events reported in literature are categorized by System Functions. We indicate whether the events are labeled as positive of negative and give an overview of the total amount of events per function.

The historical event analysis was partly validated by interviews with various actors in the field ${ }^{6}[18]$.

\section{The case of Dutch biomass gasification}

\subsection{Gasification technology}

The traditional way to convert biomass into electricity is through biomass combustion. The hot exhaust gases of the combustion process are subsequently used to produce steam that is processed through a steam turbine to generate electricity. An innovative and more efficient method is gasification of biomass. In this case biomass is combusted in an oxygen-starved environment, where the end products are $\mathrm{CO}$ and $\mathrm{H}_{2}$ gases (so called product gas or syn(thesis) gas). In contrast to solid biomass, this producer gas can be fed into a gas turbine to produce electricity at a much higher efficiency (35$40 \%$ ) than combustion (25-30\%) [15,19,20]. Biomass gasification is a flexible technology, since product gas can be used not only to produce electricity but also feedstock for chemical processes [15]. However, there are some fundamental requirements that limit the flexibility and efficiency of biomass gasification technology. The first is that a constant and sufficient supply of biomass has to be guaranteed for an installation to be able to run efficiently. Also, there is a need to ensure the quality and type of biomass. The cleaner the biomass, the lesser the costs that are involved in complex cleaning processes. Furthermore, dry biomass is more efficient than wet biomass, since no additional drying is needed. Finally, the type of gasifier used also determines the size of the installation. For small-scale applications $(<5 \mathrm{MW})$ fixed bed gasifiers are more efficient, whereas fluidized bed gasifiers are more efficient for large-scale applications ( $>5 \mathrm{MW})$ [20-22].

In this paper, we focus on biomass gasification plants where only biomass is gasified. Combined gasification of coal and biomass is not included as coal is the major feedstock used and the biomass share is only marginal, resulting in other technical properties than full biomass gasification [23]. We are aware of the experimentation of coal and biomass co-gasification in the large-scale (205 MW) coal gasification plant called 'Buggenum', but due to the above-mentioned reason, we will not include the trajectory of this project [24-26]. In addition, we focus on the use of biomass gasification for electricity production. Biomass gasification as for the production of transportation fuels (e.g. Fischer-Tropsch

\footnotetext{
${ }^{6}$ Dr. Andre Faaij, Associate Professor, Department of Science, Technology and Society, Utrecht University (2005); Professor Cees Daey Ouwens, initiator of the North-Holland project (2005); Dr Wim Willeboer, Senior project manager of the biomass gasification project of the Amer-plant (2005). Additional interviews are included that have been carried out in a previous study [18]: Ir. Kees Kwant, program leader for EZ and VROM at Novem (2003); Ir. H.E.M. Stassen, founder of BTG (2003); Dr. Andre Faaij (2004); Professor Cees Daey Ouwens (2003); Dr. Wim Willeboer (2004).
} 
fuels) is developed in quite a different innovation system. Therefore, it is not analyzed in detail but briefly sketched in order to illustrate the dependencies between both innovation systems.

\subsection{Historical overview of biomass gasification from 1980 to 2004}

\subsubsection{The hype of biomass gasification}

The main attention for biomass gasification in the Netherlands starts in the early 1990s. In the previous period, the Dutch government mainly stimulates research on alternative energy sources by publishing formal policy documents (1982 - White Paper on Renewable Energy; 1989 - National Environmental Plan (NMP); 1990 — White Paper on Energy Saving). However, these official documents are not backed up by other policy initiatives, which results in low funds for research on renewable energy; the engagement of implementation remains on general terms and on a voluntary basis [27-29].

At the beginning of the 1990s, two urgent problems are identified. The Netherlands lack sufficient landfill space for waste, resulting in several knowledge development programs set up by Novem, ${ }^{7}$ to reduce the amount of final waste by converting waste into useful energy (1989 - EWA program; $1990-\mathrm{NOH}$ program, 1992 - EWAB program) [30]. In addition, the awareness of the negative consequences of using fossil fuels increases, causing the need to develop and implement alternative energy conversion technologies to become more urgent [31]. These two problems guide the search towards new technologies that could solve these problems (F4) and create legitimacy for new development paths (F7).

The idea for large-scale biomass gasification is until now still rooted in Dutch research on coal gasification and development activities of small-scale biomass gasification units for developing countries. However, positive results obtained abroad incite the idea to use biomass gasification as an alternative conversion technology for waste surplus in the Netherlands [32,33]. In addition, the province of NorthHolland ${ }^{8}$ sets policy aims to provide a clean, sustainable and affordable energy supply by combining wind energy and biomass gasification (see the next section for a detailed description of the North-Holland project) [34]. This triggers the commission of an inventory studies for gasification of wet biomass wastestreams for electricity production, where it is found that these biomass streams can also be used for gasification and that they reduce costs due to their negative value [35]. In addition a study trip to biomass gasification projects in Sweden $9,{ }^{10}$ and Finland ${ }^{11}$ is organized by the Dutch 'Biomass Technology Group (BTG)', to obtain more knowledge about the high potential of biomass gasification technology and the possibility to set up such plants in the Netherlands [36,37]. During the same period, Novem publishes a

\footnotetext{
${ }^{7}$ Novem is an agency of the Dutch Ministry of Economic Affairs focusing on energy and environment.

${ }^{8}$ Provincial Council of the province of Noord-Holland (North-Holland).

${ }^{9}$ Since 1986 there are nine small-to-medium scale (5-10 MWth) 'Bioneer' fixed bed gasifiers operating in Sweden and Finland [15,37].

${ }^{10}$ Inl the late 1990 s, pressurized gasification technology is successfully demonstrated in the world's first complete BIG-CC power plant in Värnamo, Sweden. The plant aims at demonstrating the complete integration of a gasification plant and a combined-cycle plant, fuelled by biomass; the basic idea is to demonstrate the technology rather than to run a fully optimized plant. Between 1996 and 2000 a demonstration program is run to verify status and future potential of BIG-CC from a technical and economical point of view, but after the demonstration program is concluded, the plant is mothballed in 2000 since it is not economical to operate the plant given the low electricity prices in Sweden [15,37].

${ }^{11}$ In 1998 the commercial demonstration of the Lathi gasifier (60 MWth) is realized and is still operational today. In 2002 a similar plant (50 MWth) to that at Lahti is taken into operation in Ruien, Belgium [15,37].
} 
report that demonstrates that biomass gasification of energy crops like poplar and miscanthus for electricity production can also be quite profitable, which has put biomass gasification on the political agenda. The report states that electricity production is preferred to biofuels' production from conventional agricultural crops [31]. This major impact report shifts the current guidance of the search away from the use of biomass for automotive fuels towards the use of biomass for electricity by means of gasification (F4). This report triggers more research; desktop studies show that biomass gasification has a higher energy efficiency than biomass combustion (37-40\% vs $25-30 \%)$ and that production costs can be reduced by using biomass waste streams instead of energy crops [6,35,38-41] (F2). Due to these positive characteristics, the sustainable energy sector expresses high expectations of biomass gasification [42-45] (F4). In addition the EU 'Thermie' program ${ }^{12}$ is started and several projects receive financial support from it (e.g. Zeltweg, Austria; Lathi, Finland; Amer-plant, The Netherlands; Arbre-project, UK) [15]. Also, Shell shows interest and invests in a biomass gasification project in Brazil; however the project is not realized [32]. As a result, and in a very short time, biomass gasification is considered to be equally useful as other competing renewable energy technologies, as the following quote shows:

The contribution of biomass to the energy supply is gaining more and more importance. The most realistic routes that can be used for the production of electricity are either gasification or cocombustion of biomass in existing installations (EPON-project), combined-heat-and-power (CHP) application and the conversion of biomass into biogas. [46]

The high expectations of biomass gasification in this period are also reflected in the short development time that is expected for commercialization of the technology, and in the plans to invest in technology development. Braber et al. [47] state the following:

In the coming years, more emphasis will be put on gasification, since this technology has the potential to be cost-effective and to convert waste and biomass with a high energy efficiency. Lots of efforts are expected to be necessary to achieve these expectations, since in 2000 it will be evaluated whether gasification can be implemented on a large scale. [47]

Knowledge development indeed picks up. Studies are carried out (F2), which show that wet biomass (organic waste, sludge, etc.), only thought to be suitable for digestion or fermentation, can also be used for gasification, providing additional biomass resources for gasification and higher energy output than for digestion $[6,48]$ (F6). In addition, technological problems are not considered to be a major obstacle, as the next fragment shows:

The gasification of organic household waste is researched by the Department of Science, Technology and Society at Utrecht University. Since no compost is being produced during gasification and due to its lower conversion costs, this conversion system has chances to become a realistic option. The practical problems, cleaning the syn-gas from alkali- and heavy metals, do not form any unsolvable problems. [41]

These expectations result in a specific research program, the 'National Biomass Gasification Research Program ${ }^{13}$, by Novem, aiming to demonstrate biomass gasification technology in a number

\footnotetext{
12 Thermie — Non-Nuclear Energy Program, 1990-1994.

${ }^{13}$ In Dutch: Nationaal Onderzoek Biomassa programma, NOB.
} 
of projects. These projects not only lead to knowledge development (F2) and more financial resources (F6), but also guide the search by highlighting the importance of this technology (F4). The aim of the program is the following:

Special emphasis will be put on the set up of a circulating fluidized bed gasifier for the gasification of biomass waste. The aim is to demonstrate the techno-economic feasibility and to provide long-term perspectives for this technology on the large-scale conversion of waste and biomass. [47]

To recapitulate, positive results from abroad and a high impact study (Novem) puts biomass gasification on the agenda and quickly results in the rise of expectations for biomass gasification in the early 1990s. This, in turn, triggers a series of activities that can be classified as Knowledge Development, Guidance of the Search, and Mobilization of Resources. The rise of a virtuous cycle is observed, since positive results from research (F2) result in high expectations of biomass gasification (F4), which, in turn, result in the set up of research programs in the context of which demonstration projects are set up (F2, F6).

However, not all System Functions in the Biomass Gasification Innovation System receive attention in that first period. In addition, there are several critical voices that warn against following the hype without first solving technical problems and obtaining consistent support from the government. One of the leading figures in this field expresses it as follows:

There is no clear-cut national program about biomass in the Netherlands. Some projects are being prepared, but mainly for the co-combustion of biomass in coal plants. [49]

An additional problem is the lack of market formation (F5) by the Dutch government. To attract more research funds (F6) and to get entrepreneurs interested (F1), a clear vision of the future market for these types of technologies is necessary. At this time, there are no subsidies, feed-in tariffs, or launching customer activities of the government. A spokesperson from an energy distribution company states the following:

There are possibilities to set up gasification plants in the Netherlands, since there is enough hay and verge grass that could be used as short-term options. However, who is going to pay for it? [50]

Finally, there are some critical voices that warn against rushing the set up of large-scale plants (due to high expectations and promises (F4) and ignoring technical problems), as long as the technology has not been proven, as expressed by Mr. Smakman, project leader of the EWAB program [50,51].

... A long-term development is needed before gasification will be established in the Netherlands and the future of gasification is difficult to predict, since there is no experience and expertise in the Netherlands for this technology. Additionally, practice is unmanageable, so the new technology has to be 'proven' first, before it will be accepted. [50]

In this period, two projects aiming to realize large-scale application of biomass gasification dominate the dynamics of the Biomass Gasification Innovation System. Both projects receive much attention in the Dutch energy system and they trigger many other processes in the IS, as we will see in the following paragraphs. 


\subsubsection{The ups and downs of the North-Holland project}

In 1993, the Province of North-Holland, the coordinator of the national energy companies, SEP, ${ }^{14}$ several energy companies, UNA and PEN, and researchers from $\mathrm{ECN}^{15}$ design plans for the first largescale gasification project in the Netherlands (F1, Entrepreneurial Activity) [52-54]. Several feasibility studies are carried out over the years to assess the location, scale, and biomass streams [54-58] (F2, Knowledge Creation). At the end of 1994, the pre-studies are completed and the decision is taken to gasify waste wood, thinning and other residues in a $30 \mathrm{MW}$ installation linked to a combined heat and power (CHP) system in the region of North-Holland. The expectations are high and it is predicted that the plant will be constructed at the beginning of 1998, run for a few years on trial and subsequently be sold to a user, for example UNA [55].

During the project, several established actors in the Dutch energy system express their serious interest in this technology, which results in an advocacy coalition formation (F7). This, in turn, leads to a mobilization of resources (F6) (1.5 million EUR for the complete project) and more research to reduce the initial technical and economic uncertainties (F2). The entire initiative can be regarded as the creation of a niche market for gasification technology (F5), since the national government - backed up by the consortium of private parties involved - indirectly stimulates the potential returns by encouraging provinces to incorporate renewable energy into their energy mix [34]. The first phase of the NorthHolland project therefore boosts several functions in the Biomass Gasification Innovation System.

Negotiations continue until 1997. However, one year before the construction is supposed to start, experiments demonstrate that the economics of the project are disappointing, in contrast with previously favorable outlooks, and that the North-Holland project is not economically profitable $[21,59]$. In addition, there are uncertainties about the wood delivery. No suitable wood delivering company is found that provides long-term contracts (10 years), due to the uncertainty of wood prices [34] (Lack of resources (F6)). In addition, the pre-building time span stretches in such a way, that the liberalization of the energy market starts to interfere with the project plans. This national liberalization movement (which started in 1998 for the entire electricity sector) turns out to have dramatic consequences for this project, one of which is the growing fear that the SEP agency, one of the project partners, will be discontinued [34,60]. Furthermore, energy companies become reluctant to invest in high-risk projects. The fact that biomass gasification is an unproven technology results in insurmountable technological uncertainties. Therefore, the guidance of the search quickly shifts away from emerging energy technologies such as gasification (F4) $[34,60]$.

The delays for realization of biomass units is not only due to technical aspects, but due to the energy world that is reluctant to take high risks in the continuously proceeding liberalization and due to the reduction of oil prices. Expensive and risky projects are not realized without problems by the free market anymore. [61]

\footnotetext{
${ }^{14}$ From 1948 until 1998, the 'SEP' was the coordinator of the national energy companies.

15 ECN is the Energy research Centre of the Netherlands; From 1994 ECN carries out several feasibility studies, among others for the North-Holland project, on various biomass streams (organic waste, wood, paper, etc.) and on the economical and technical potential of integration of a gasifier and a gas turbine. In 1996 a circulating fluidized bed, BIVKIN, is set up, with the aim to collect information about the gasification process and properties of different biomass streams. In a short period of time the gasifier becomes a reliable installation due to the collaboration of ECN, Stork, HoSt, Afvalzorg and Novem. In 1999 the gasifier is equipped with a gas cleaner developed by HoSt and plans are made to apply the technology commercially [57].
} 
Finally, the Province of North-Holland and the energy company ENW (successor of PEN) decide to abort their ambitious gasification project in 1998 [62-64]. The final decision is caused by a build-up of disappointments in the technology and growing disagreement between the parties involved with respect to various technical and economical aspects, i.e. the unreliability of the technology, high costs and high risks [60].

\subsubsection{The tedious trajectory of the Amer-plant}

The second large-scale project is started in 1996, three years after the initiation of the North-Holland project, by a consortium of PNEM, ${ }^{16} \mathrm{NUON}^{17}{ }^{17} \mathrm{EPZ}^{21}$ and $\mathrm{BFI}^{18}(\mathrm{~F} 1)$. The size of the plant is planned to be $30 \mathrm{MW}$ with an atmospheric circulating fluidized bed (ACFB) gasifier for co-firing, where the combustible gas from the gasifier will be co-combusted in the nearby coal-fired power plant 'Amer-plant', operating with a CHP-unit, delivering $600 \mathrm{MWe}$ of electrical power as well as up to $350 \mathrm{MW}$ th of district heating [65-69]. Once again, the expectations are high. It is promised that the plant will be operational in 1998 , as shown by the following quote (F4) [68]:

This plant will convert construction- and demolition wood into combustible gas, which can be cocombusted in the Amer-plant. There are several advantages of wood gasification: 46.000 ton coal will be saved, 115.000 ton $\mathrm{CO}_{2}$ emission reductions will be achieved and 100.000 ton less wood waste will be dumped. From a feasibility study it is evident that such a plant will be profitable. If the construction starts by the end of 1996, then the plant will be operational in 1998. [68]

However, shortly after, the consortium aborts the project because the use of waste wood proofs to be economically unfeasible for this application (F6). It turns out that it is more profitable to export the cleaned demolition wood to Sweden, than to use it for biomass gasification in the Amer-plant. This results in a lack of biomass resources to run the plant [70]. However, expectations of biomass gasification technology are still high and in 1997, EPZ restarts this project. This time, however, with a different wood delivery company [71]. The preparations pass off quickly and plans are that the plant will be operational in two and a half years:

The plans for constructing a wood gasification plant on the site of the Amer-plant in Geertruidenberg by the electricity company EPZ is in an advanced stage. (...) The internal publication of EPZ writes that 'this is about a world premier'. The technology is new and has not been applied on commercial scale in combination with an electricity plant. [71]

In 1998, subsidies are received from the European Union (F6) (Thermie program, 5 Mio. EUR) and the Dutch government $\left(\mathrm{CO}_{2}\right.$-emission reduction plan, 6 Mio. EUR) and in 1999 the construction of the gasification plant enters the last phase; it should be finished by the end of the year [71-73]. In 2000, the construction is completed and the installation should be operational. The project receives much exposure in the (renewable) energy system of the Netherlands, as shown in the following quote:

There are high expectations for the Amer-plant, where the gasified biomass is blown into the nearby coal plant. This project is just starting and any positive experiences could mean the long awaited breakthrough. [74]

\footnotetext{
16 Dutch energy companies.

${ }^{17}$ NUON and EPZ are energy production companies.

18 Waste processing company now called SITA.
} 
However, positive experiences fail to occur. Technical problems hamper a smooth running of the gasifier, making modifications necessary. The major problems are the gas cooling (from $900{ }^{\circ} \mathrm{C}$ to $220^{\circ} \mathrm{C}$ ) and gas cleaning, since the contractor, Lurgi, ${ }^{19}$ has no experience with waste wood, but only with coal. The behavior of the waste wood ash is different, clogging up the exhaust and causing congestion $[15,69]$. In 2001, a temporary modification is carried out, marking a second phase of operation, in which numerous other - more structural - modifications are carried out. Both the gas cleaner and gas cooler are rebuilt to accommodate the properties of the ashes. Finally, in 2003, the plant is operational nearly fulltime, as most of the problems - especially the gas cooling problem - have been solved due to the modifications [75]. From 2004 onwards, the contract with Lurgi is discontinued and Essent takes over the maintenance and operation of the gasification unit, since enough knowledge and experience (F2) have been built up over the years. Finally, on the 1st of September 2005, after seven wearisome years (during which only few kilowatt-hours have been produced), the modifications of the plant are finalized [75].

The story of the Amer-plant shows that the high expectations of biomass gasification were just too optimistic. Note that in 1992, the gas-cleaning problem was considered to be a technical problem, which could easily be resolved. However, it turned out to be one of the main problems, postponing a smooth functioning of the Amer-plant for 7 years. Part of the reason for this problem is that the contractor did not have the necessary experience and expertise to foresee and resolve technical problems that would occur during biomass gasification. These problems might have been avoided if an experienced contractor would have been involved.

\subsubsection{The breakdown of expectations}

Now that we have described two projects more in detail, we will return to describing the developments at system level.

In 1998, the energy market is liberalized and the waste market deregulated. Despite the high expectations in the previous period, biomass gasification failed to prove itself as a reliable, economically attractive, and efficient technology. The North-Holland project is aborted in this year and it is still unclear how the Amer-plant will turn out to perform. The choice of the main industrial parties in the liberalized market is not to use biomass gasification technology:

Energy companies have not embraced biomass gasification yet; partly it is still in demonstration phase and not a proven technology yet [...]. Furthermore, the liberalization of the energy market makes energy companies reluctant to take risks. Companies prefer proven technologies rather than doing innovative things. [76]

As a result, hardly any research and development on biomass gasification for electricity production occurs in the following 2 years (F2). The hype of gasification clearly ends here (F4) [72].

In 2000, the government antagonizes all further developments related to biomass gasification, by formulating a strict emission regime based on current coal combustion plants. The few initiatives for smallscale biomass gasification plants ${ }^{20}$ are immediately unprofitable under the new rules, since now additional gas cleaning is needed to comply with these rules (F4) [77]. As a consequence, no further research and

\footnotetext{
${ }^{19}$ Lurgi: German technology company operating worldwide in the fields of process engineering and plant contracting. The Lurgi process is one of the original developers of conventional gasification processes (www.lurgi.de).

${ }^{20}$ Between 1993 and 2000 several small-to-medium-scale (100 kW to $8 \mathrm{MW}$ ) gasification projects are planned and some are set up by BTG, TNO, ECN, Goor, HoSt, Edon, Stork, Kara, etc. [72].
} 
exploration activities are carried out (F2), bringing the development of biomass gasification for electricity production to a halt. In this period, a vicious cycle becomes dominant, since there is no guidance of the search (F4), resulting in a lack of demand and expectations (F4), causing no more research to be funded (F5) and carried out (F2).

\subsubsection{Revival of biomass gasification?}

However, in the period 2002-2004, a revival of biomass gasification seems to occur. The drive for this revival comes from a different direction. The European Union stimulates its member states to substitute part of the fossil-based automotive fuels by biofuels. In the Netherlands, so-called 'second generation' (2G) biofuels - partly based on gasification technology - are preferred to the so-called 'first generation' (1G), which can be associated with conventional technologies [78,79]. This results in publicly financed research programs - most notably the GAVE platform - to develop the conversion technologies necessary for the production of these fuels, e.g. most notably the NECST/NEO program in 2001 and the GAVE subsidy programs in 2001 and 2002 (F2, F4) [80,81]. From 2001 on, a large number of entrepreneurs and research institutes - Shell, ECN, etc. - conduct fruitful R\&D on gasification processes for the production of Fischer-Tropsch Diesel and hydrogen. As a consequence, this period is characterized by many renewed guidance activities on behalf of the national government (F4) and R\&D activities by entrepreneurs and researchers $(\mathrm{F} 2)[82]$.

The chances for a large-scale application of biomass in the Netherlands are high. Also the use of biomass for biofuel production is expected to increase to $10 \%$ in Europe, this could be achieved from linseed or rapeseed or by gasification of biomass. [83]

However, when the pressure of the EU to comply with the biofuels directive increases in 2003-2004, the $2 \mathrm{G}$ biofuels technology is still not ready for market introduction. As a result, the support for the $2 \mathrm{G}$ biofuel trajectory shifts to the background as the conventional fuels become more popular [84]. Finally, history seems to repeat itself as technological optimism turns into disappointment within a very short period of time.

\section{Functional pattern}

In this section, the functional patterns are described by using graphical representations; the number of events per function per year is plotted over time. The patterns observed are explained by referring to specific events within the storyline, as given above.

All figures show a remarkable absence of activity before the 1990s (see Figs. 2-6). In the 1990s things change; the main driving force within the Biomass Gasification Innovation System now is the search for alternative energy technologies to replace fossil fuels. As a result, several research programs are set up to assess the application of gasification technology for energy production (F4, see Fig. 5 peak in 1992). Experimentation and research provide positive results (F2, see increase in knowledge development activities from 1991 to 1998 in Fig. 3). Expectations grow as biomass gasification is increasingly mentioned as the solution to a sustainable energy production (F4, see Fig. 5 peak in 1995 and 19971998). This sequence of events corresponds with a positive interaction between the System Functions: the more research is done (F2, Fig. 3), the more positive results are obtained and publicized (F3, Fig. 4), the 


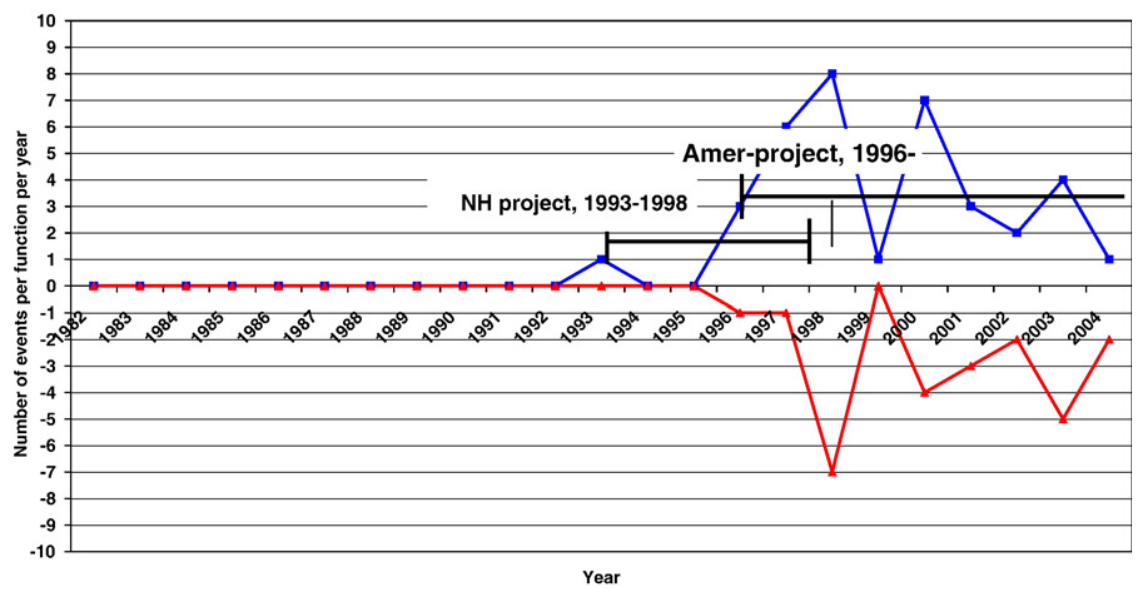

Fig. 2. Activity pattern of function 1: Entrepreneurial Activities.

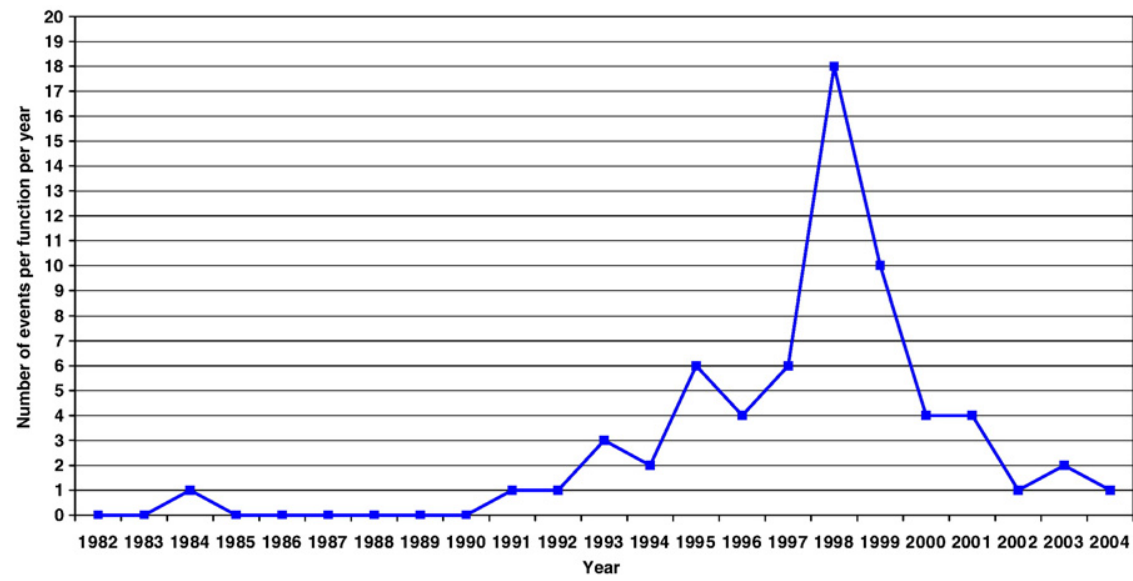

Fig. 3. Activity pattern of function 2: Knowledge Development.

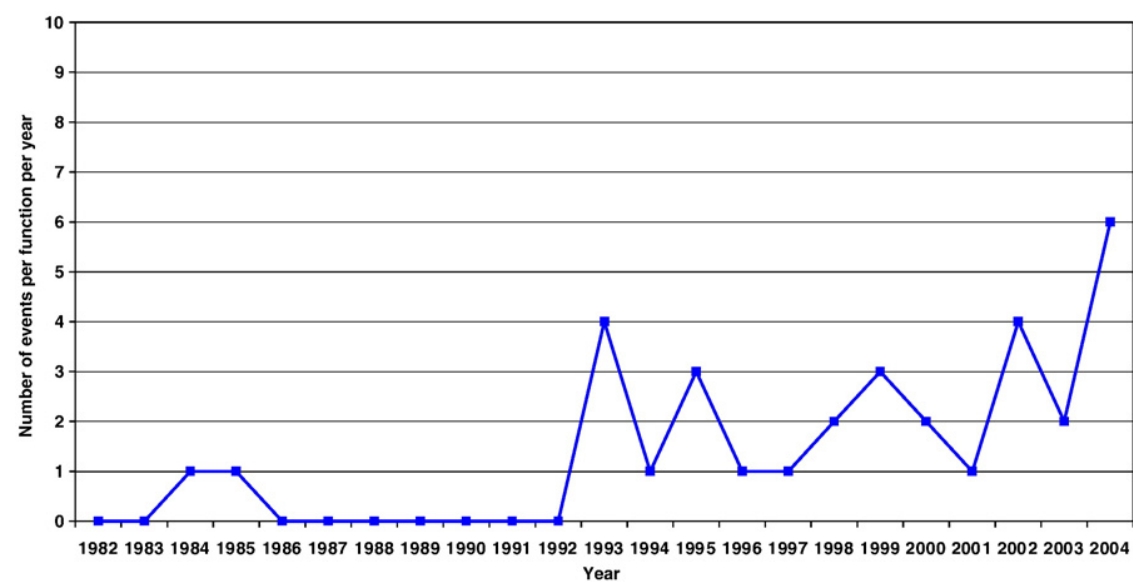

Fig. 4. Activity pattern of function 3: Knowledge Diffusion. 


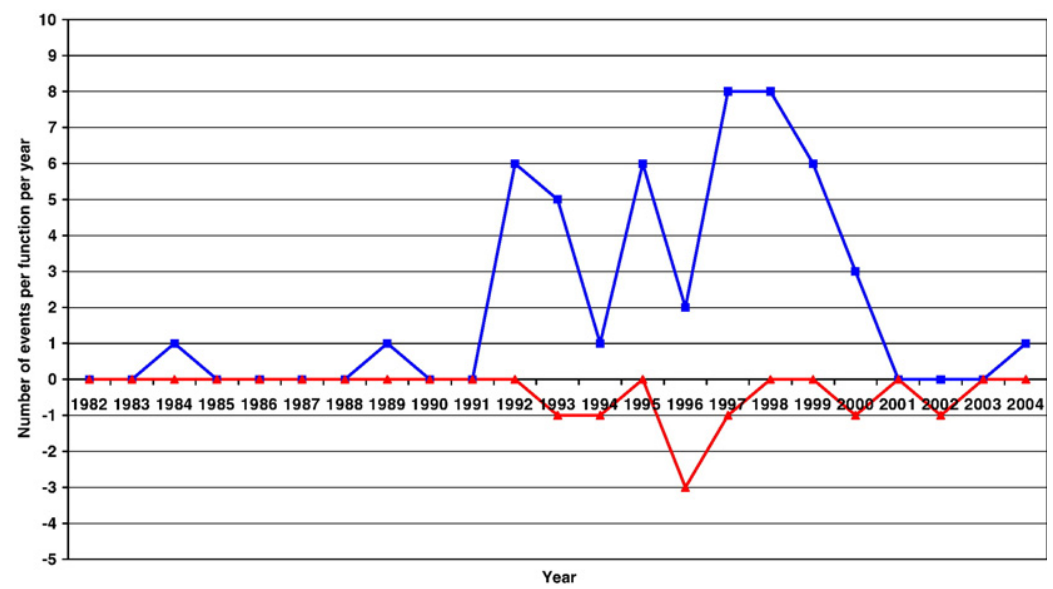

Fig. 5. Activity pattern of function 4: Guidance of the Search.

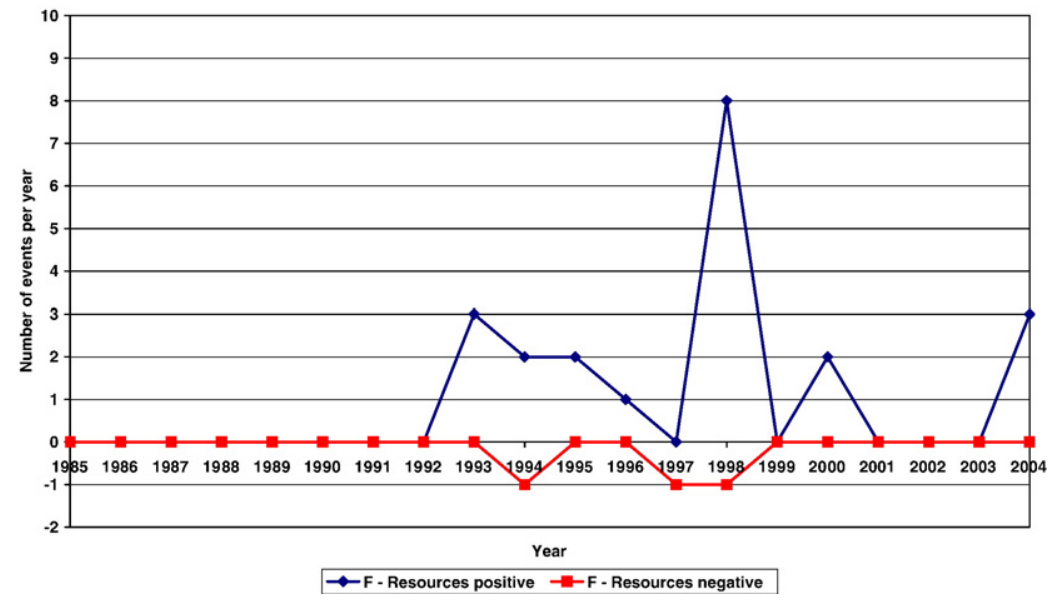

Fig. 6. Activity pattern of function 6: Resource Mobilization.

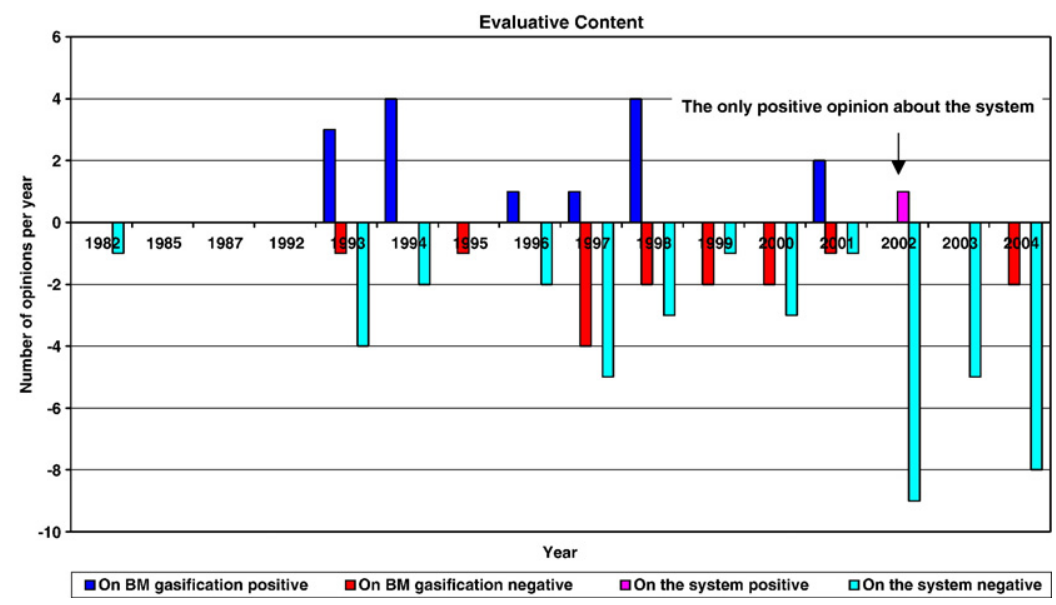

Fig. 7. Activity pattern of actors' opinions within the biomass gasification innovation system. 
more resources are allocated to the technology (F6, Fig. 6), ensuring further development of biomass gasification (F2, Fig. 3). This, in turn, stimulates entrepreneurs to take their chances and set up two largescale plants for biomass gasification (F1, Fig. 2, the two large-scale projects are marked within the graph). Throughout those years, other small-scale plants are set up as well (F1, Fig. 2, peak in 1998). Thus, between 1992 and 1998, different System Functions are fulfilled, driven by high expectations. A pattern of function reinforcement emerges, resulting in the build-up of a virtuous cycle.

However, in this period (1992-1998), actors of the Biomass Gasification Innovation System express their disappointment and reveal system flaws (see Fig. 7 and the quotes in the gasification storyline). This shows a lack of activities, resulting in some functions to be hardly or negatively fulfilled. For example, actors express their disappointment; their main concern is the fact that the national government does not provide uniform, consistent, and long-term regulations throughout the years (see Fig. 7, negative opinions about the system). In this figure, the actors' opinions are counted over the years; the representation shows that there are more negative opinions about the system than positive ones (only one in 2002). Thus, we see that the technology itself is perceived as positive, but the Innovation System is criticized heavily. In addition, some actors are skeptical about the hype around biomass gasification technology; they warn entrepreneurs not to be carried away without proving the technology first (see Fig. 7, negative opinions about biomass (BM) gasification). In retrospect, these voices seem to have made an accurate analysis. Furthermore, there are expressions about the lack of resources (see Fig. 6 negative line) and the lack of support from advocacy coalitions (F7, no graphical representation due to lack of data). Nonetheless, in the period of 1992-1998, it seems that these negative or lacking functions are outweighed by the positive build-up of activities, due to the hype and high expectations that dominate that period.

However, as the energy market is liberalized in 1998, the high expectations are shattered quickly. Unsolved technical problems and a poor economic performance ensure that biomass gasification is not ready for introduction in a turbulent market environment. This results in the discontinuation of the NorthHolland project (Fig. 2, see markings in the graph) and the closure of several other small-scale plants that had been set up in previous years (Fig. 2, see negative peak of projects aborted in 1998). In addition, most of the other activities in the Innovation System are discontinued as well; entrepreneurs and energy companies are reluctant to take high risks within the context of a liberalized market. No more research and studies are carried out (Fig. 3, drop of positive line after 1998), allocation of resources (F6, see Fig. 6, drastic drop of positive line in 1998) and specific guidance (F4, Fig. 5, drop after 199) for biomass gasification are discontinued. In addition stricter emission regulations are introduced in 2000, which results in the shut down of several small-scale plants (see Fig. 2, negative line between 1999 and 2004 representing the shut-down of small-scale plants). Thus, the sequence of events after 1998 results in the collapse of the previous virtuous cycle.

The revival around biofuels seems to bring biomass gasification technology back on the political agenda as a key technology for $2 \mathrm{G}$ fuels, however no increase of other activities occurs then. The critics on the IS remain highly negative, due to inconsistent government policy that did not manage to realize a breakthrough for the $2 \mathrm{G}$ biofuels (see Fig. 7 negative opinions about system).

\section{Conclusions}

Despite the promises of high-energy conversion efficiency and the wide variety of applications, biomass gasification has not been successfully developed and implemented in the Netherlands. We applied the Functions of Innovation Systems framework to obtain more insight in the dynamics of the 
Biomass Gasification Innovation System and the determining factors that induced or blocked the evolution of this new technology. The most important insights gained are highlighted below.

The main inducement factors for the evolution of biomass gasification - in the period studied - are the high expectations and optimism about biomass gasification being an efficient and profitable energy production technology. This results in the initial hype where the build-up of the Biomass Gasification Innovation System becomes a reality; System Functions such as entrepreneurial activities, knowledge development, knowledge diffusion, guidance of the search and resource allocation mutually reinforce each other in this period. This virtuous cycle lasts for a period of 6 years (1992-1998).

One of the important blocking mechanisms arises when two drastic changes occur in the institutional system within which biomass gasification technology develops. Firstly, when the energy market is liberalized in 1998 and, secondly, the emission regulations are changed, biomass gasification technology has not booked enough positive results to be accepted as a proven technology. Many actors become reluctant to further support biomass gasification, which results in the abortion of various initiatives and activities. This is reflected in the decline of function fulfillment, i.e. no more entrepreneurial activities, decreasing knowledge development, no more specific positive guidance, and no more resources allocated to biomass gasification.

The main blocking factor - throughout the entire period - is the absence of the national government with respect to a clear and consistent policy towards biomass gasification. Over the years, the opinions of actors within the biomass gasification innovation system show that there is an absence of available public resources, guidance, and other forms of support for biomass gasification.

From our case it seems reasonable to assume that gasification technology still needed a protective environment to be able to further develop. Instead, the above-mentioned events forced the entrepreneurs to move to a free market environment and to either accept or completely reject the technology. When a new technology is served-off like this, two opposite conclusions can de drawn. The first is that the innovation system was successful in screening out unfit technologies and the second is that the innovation system did not function well enough to protect emerging technologies in the market environment. In this case, clearly the second conclusion needs to be drawn since for a technology to be declared incompatible, many experiments should be carried out first that show that the technical problems cannot be solved. In the Netherlands, though only one project was realized and after several years the technical problems were solved. For an emerging technology to have any impact, it normally has to go through a lengthy, uncertain and painful process of trial and error. However, in this case, only one project went through this process, all other projects were already dismissed before the first trial phase. Thus, the general conclusion that can be drawn from this, is that a structural misalignment occurred between the institutional framework within which the technology could have been developed, on the one hand, and the technical requirements on the other. Here, the government should have intervened by creating the right conditions for emerging technologies like biomass gasification, for instance by stimulating the System Functions.

As a final point, the System Functions approach proved useful in ordering the large number of events that took place in this process of change and it allowed for a quantitative analysis that proved to be very useful in underpinning the empirical storyline. Usually, Innovation System studies look at the structure of the system and the diffusion of a technology is the performance indicator. However, in the case of emerging technology, no diffusion has taken place yet, thus other performance indicators are needed. By using the System Function approach we have identified what really happened within the system. This allowed us to identify the weak and strong points in this development and we were able to draw lessons from it. Also, the fact that we analyzed this wearisome story in terms of System Functions, will allow us to compare this case with more successful developments. In this way we can learn how functional patterns differ in troublesome 
and successful processes of technological change. This is crucial information when the aim of policymaking is to contribute to well functioning sustainable energy innovation systems.

\section{Acknowledgements}

The authors would like to thank Dr. Andre Faaij, Professor Staffan Jacobsson, Dr. Koen Frenken, Dr. Frank Geels and Dr. Iris Lewandowski for their useful comments on previous versions. Special thanks also to Drs. Anouk Florentinus who had a significant role in empirical data collection. We would also like to thank Professor Cees Daey Ouwens and Dr. Wim Willeboer for their time and comments. We are also very grateful for the useful comments of two anonymous reviewers. Finally, we would like to thank the 'Knowledge Network for System Innovations and Transitions (KSI)' and the 'Netherlands Organization for Scientific Research (NWO)' for their financial support.

\section{References}

[1] IEA, Renewable Energy Markets — Fact Sheet, 2005.

[2] S. Jacobsson, A. Johnson, The diffusion of renewable energy technology: an analytical framework and key issues for research, Energy Policy 28 (9) (2000) 625-640.

[3] G.C. Unruh, Understanding carbon lock-in, Energy Policy 28 (12) (2000) 817-830.

[4] S. Jacobsson, A. Bergek, Transforming the energy sector: the evolution of technological systems in renewable energy technology, Ind. Corp. Change 13 (5) (2004) 815-849.

[5] M.P. Hekkert, et al., Functions of innovation systems: a new approach for analysing technological change, Technol. Forecast. Soc. Change (2006), doi:10.1016/j.techfore.2006.03.002.

[6] v.J. Doorn, Gft-vergassing goedkoopst, Duurz. Energ. 5 (1992) 22.

[7] E\&MSpectrum, Vergassen GFT-afval goedkoper dan composteren, Energ. Milieuspectr. 1 (1993) 5.

[8] E\&MSpectrum, Biomassa vergassen: een technologische uitdaging - Energiebedrijven studeren op mogelijkheid demonstratie uitdaging, Energ. MilieuSpectr. 6/7 (1993) 22-26.

[9] E\&MSpectrum, Nederland rijp voor de demonstratie van biomassa — Vergassing van organisch afval en hout kansrijk, Energ. MilieuSpectr. 2 (1993) 30.

[10] J. Schot, R. Hoogma, B. Elzen, Strategies for shifting technological systems — the case of automobile system, Futures 26 (10) (1994) 1060-1076.

[11] C. Edquist, The systems of innovation approach and innovation policy: an account of the state of the art, DRUID, 2001, Aalborg.

[12] T.J. Foxon, et al., UK innovation systems for new and renewable energy technologies: drivers, barriers and systems failures, Energy Policy 33 (16) (2005) 2123-2137.

[13] A. Johnson, S. Jacobsson, Inducement and blocking mechanisms in the development of a new industry: the case of renewable energy technology in Sweden, in: R. Coombs, et al., (Eds.), Technology and the Market. Demand, Users and Innovation, Edwar Elgar Publishing Ltd, Cheltenham, 2001, pp. 89-111.

[14] X. Liu, S. White, Comparing innovation systems: a framework and application to China's transitional context, Res. Policy 30 (7) (2001) 1091-1114.

[15] M. Morris, et al., Status of Large-scale Biomass Gasification and Prospects, 2005.

[16] A.H. van de Ven, et al., The Innovation Journey, Oxford University Press, 1999.

[17] M.S. Poole, et al., Organizational change and innovation processes, theories and methods for research, ed. O.U. Press, 2000.

[18] A. Florentinus, The development of biomass gasification - a comparison between the Netherlands and New Zealand, Utrecht University, 2004.

[19] A. Faaij, et al., Gasification of biomass wastes and residues for electricity production, Biomass Bioenergy 12 (6) (1997) $387-407$.

[20] R.H. Williams, E.D. Larson, Biomass gasifier gas turbine power generating technology, Biomass Bioenergy 10 (2-3) (1996) 149-166. 
[21] A. Faaij, B. Meuleman, v.R. Ree, Long-term perspectives of Biomass Integrated Gasification/Combined Cycle (BIG/CC) technology; costs and electrical efficiency, NWS and ECN, Utrecht, 1998.

[22] A. Faaij, Biomass Background, Utrecht University, Utrecht, 1997.

[23] R. Didde, Een mooi ding in de etalage, de Volkskrant, 2001.

[24] M. Aarder, Afval voor de centrale, de Volkskrant, 2000.

[25] Postma/Corr, in ANP. 2000.

[26] R. Didde, De scharrelkip houdt het licht aan, de Volkskrant, 2000.

[27] NE\&S, Het inkonsistente nederlandse energiebeleid, Nieuwsbrief Energie and Samenleving, 1982, p. 12.

[28] K. Blok, Overheid drukt duurzame energie niet door, Duurzame Energie, 1985, pp. 4-5.

[29] G.P.J., Verbong, et al., Een kwestie van lange adem; De geschiednis van duurzame energie in Nederland, ed. Aeneas. 2001, Boxtel.

[30] DE, 1989 - EWA programme, 1990 - EWAB programme NOVEM, Duurz. Energ. 5 (1992) 35.

[31] E.H. Lysen, et al., Feasibility of biomass production in the Netherlands, in: NOVEM (Ed.), EWAB, 1992.

[32] A.E. Carpentieri, E.D. Larson, J. Woods, Future biomass-based electricity supply in Northeast Brazil, Biomass Bioenergy 4 (3) (1993) 149-173.

[33] R.H. Williams, E.D. Larson, Advanced gasification-based biomass power generation, in: T.B. Johansson, et al., (Eds.), Renewable Energy: Sources for Fuels and Electricity, Island Press, Washington D.C., 1993, pp. 729-785.

[34] C. Daey Ouwens, Interview, 2005 Utrecht.

[35] A. Faaij, K. Blok, E. Worrell, Gasification of wet biomass waste-streams for electricity production, 1992 Florence (Italy).

[36] MilieuTechnologie, Verslag studiereis biomassa-vergassing Zweden en Finland, MilieuTechnologie 5 (9) (1993) 12.

[37] K. Kwant, H. Knoef, Status of Gasification in countries participating in the IEA Bioenergy and GasNet activity (task 33), SenterNovem, Utrecht, 2004.

[38] DE, Energie uit biomassa, Duurz. Energ. 5 (1992) 21-23.

[39] v.J. Doorn, Grotere rol bio-energie, Duurz. Energ. (1992) 20.

[40] DE, Electriciteit uit biomassa binnen handbereik, Duurzame Energie, 1992, pp. 24-26.

[41] DE, GFT-vergassing goedkoper? Duurz. Energ. 5 (1992) 27-29.

[42] DE, Transportbrandstoffen uit biomassa, Duurzame Energie, 1993, p. 19.

[43] DE, Electriciteit uit biomassa, Duurz. Energ. 3 (6) (1994) 20.

[44] MilieuTechnologie, Electriciteit uit biomassa via verbranding verder ontwikkelt dan via vergassing, MilieuTechnologie 6 $(10 / 11)(1994) 12$.

[45] R. Venendaal, H.E.M. Stassen, Vergassing van afval levert vooralsnog minder electriciteit — Twee technieken voor vergassing vergeleken met verbranding, Energ. MilieuSpectrum 8 (1994) 30.

[46] DE, Bioenergie wordt steeds belangrijker, Duurz. Energ. 10 (5) (1993) 35.

[47] K. Braber, K. Kwant, G. Smakman, Energie uit afval populair, Duurz. Energ. 12 (6) (1993) 14-15.

[48] MilieuTechnologie, Gft-afval als brandstof, MilieuTechnologie 5 (2) (1993) 10.

[49] C. Daey Ouwens, Wordt biomassa belangrijkste energiebron? Duurz. Energ. 12 (6) (1993) 10-13.

[50] E\&MSpectrum, Biomassa vergassen: een technologische uitdaging — Energiebedrijven studeren op mogelijkheid demonstratie uitdaging, Energ. MilieuSpectrum 6/7 (1993) 22-26.

[51] E\&MSpectrum, Nederland rijp voor de demonstratie van biomassa - Vergassing van organisch afval en hout kansrijk, Energ. MilieuSpectrum 2 (1993) 30.

[52] DE, De ontdekking van een nieuwe energiebron, Duurz. Energ. 1 (2) (1994).

[53] DE, Energiewinning uit biomassa begint inhaalrace, Duurzame Energie, 1995, p. 10.

[54] E\&MSpectrum, Principes en toepassing van biomassa, Energ. MilieuSpectrum 11 (1995) 13.

[55] E\&MSpectrum, Voorstudie voor 20 MW-biovergasser, Energ. MilieuSpectrum 10 (1993) 13.

[56] DE, De ontdekking van een nieuwe energiebron, Duurz. Energ. 1 (2) (1994).

[57] E\&MSpectrum, Voorstudie demo biovergasser afgerond, Energ. MilieuSpectrum 1/2 (1995) 10.

[58] DE, Energiewinning uit biomassa begint inhaalrace, Duurz. Energ. 6 (1995) 10.

[59] E\&MSpectrum, Energiebedrijven zien benutting biomassa verschillend, Energ. MilieuSpectrum 9 (1997) 24.

[60] DE, Mensen van het eerste uur: Daey Ouwens, duurzame duizendpoot, Duurz. Energ. 10 (2001).

[61] DE, Biomassa volwassen optie, Duurzame Energie, 1997, p. 38.

[62] DE, Vergassingsproject NH gaat niet door, Duurzame Energie, 1998, p. 22.

[63] Biovisie, Geen biomassavergasser voor Noord-Holland, Biovisie (1998) 8. 
[64] Afval!, Biomassavergasser in Noord-Holland gaat niet door, Afval! (7) (1998).

[65] E\&MSpectrum, ECN bouwt experimentele biovergasser, Energ. MilieuSpectrum 1/2 (1996) 6.

[66] E\&MSpectrum, Kolencentrales onderzoeken import hout, Energ. MilieuSpectrum 6/7 (1996) 14-16.

[67] MilieuTechnologie, ECN bouwt experimentele wervelbedoven voor vergassen van biomassa, Milieu Technologie, 1996, p. 12.

[68] DE, Installatie voor houtvergassing, Duurz. Energ. 2 (1996) 8.

[69] EssentEnergieBV, Co-combustion of gasified contaminated waste wood in a coal fired power plant, in Thermie Demonstration project n. SF/323/95/NL/FI, P.R.t.t. EU, Editor. 2001, Essent: Geertruidenberg.

[70] DE, Vergassingsproject Amercentrale niet haalbaar, Duurzame Energie, 1996, p. 40.

[71] DE, EPZ beslist binnenkort over houtvergassing, Duurz. Energ. (1997) 26.

[72] DE, Jaar van de vergassing, Duurz. Energ. 2 (1998) 42.

[73] DE, Internationale samenwerking in vergassingsproject, Duurzame Energie, 1999, p. 35.

[74] DE, Nieuwe hoogleraar Brem: Energie uit Biomassa is aan succes toe. 2000e. p. 36.

[75] W. Willeboer, Interview. 2005: Geertruidenberg.

[76] DE, Houtvergassing nog niet klaar voor energieneutrale woonwijk, Duurz. Energ. 3 (2004) 40.

[77] DE, Biomassa niet optimaal gebruikt, Duurz. Energ. 4 (2000) 36.

[78] Stromen, Wilgenbenzine, Stromen, 2002.

[79] NRC, Tarwesuper en koolzaaddiesel; Dure brandstoffen leiden tot hausse aan bioalternatieven, NRC Handelsblad, 2004.

[80] Stromen, Productie groen aardgas rendabel, Stromen, 2003.

[81] SenterNovem, Projecten overzicht, 2001 Utrecht.

[82] H. Boerrigter, d.H. Uil, H.-P. Calis, Green diesel from biomass via Fischer-Tropsch synthesis: new insights in gas cleaning and process design, ECN and Shell Global Solutions International, 2002.

[83] DE, Spoedig uitgewerkt plan voor transitie naar biobased economy, Duurz. Energ. 2 (2003) 34.

[84] R.A.A. Suurs, M.P. Hekkert, Naar een methode voor het evalueren van Transitietrajecten - Functies van innovatiesystemen toegepast op biobrandstoffen, Innovation Studies, Copernicus Institute, Utrecht University, 2005.

Simona O. Negro (MSc) and Roald A.A. Suurs (MSc) are PhD students at the Innovation Studies group, Utrecht University, The Netherlands.

Marko P. Hekkert is an Associate Professor of Sustainable Innovation at the Innovation Studies group, Utrecht University, The Netherlands. 